\title{
PELAKSANAAN PROGRAM PARENTING DI RAUDHATUL ATHFAL PERMATA ASSHOLIHIN
}

\author{
Endah Febyaningsih ${ }^{1}$, Nurfadilah $^{1}$ \\ ${ }^{1}$ Program Studi Pendidikan Guru Pendidikan Anak Usia Dini, Fakultas Psikologi dan Pendidikan, \\ Universitas Al-Azhar Indonesia, Jalan Sisingamangaraja, Kebayoran Baru, Jakarta Selatan 12110 \\ Penulis untuk Korespondensi/ E-mail: novanurfadilah@uai.ac.id
}

\begin{abstract}
Abstrak - Program parenting merupakan suatu bentuk kegiatan yang dilakukan untuk menyelaraskan pengasuhan dan pendidikan anak di sekolah dan di rumah. Program parenting penting didapatkan orang tua guna menambah pengetahuan terkait pengasuhan yang sesuai dengan pertumbuhan dan perkembangan anak usia dini. Tujuan penelitian ini untuk menjelaskan proses pelaksanaan program parenting dimulai dari tahap persiapan, pelaksanaan, dan evaluasi. Penelitian ini menggunakan pendekatan kualitatif deskriptif dengan teknik pengumpulan data berupa observasi, wawancara, dan dokumentasi. Analisa data menggunakan triangulasi teknik. Subjek penelitian ini berjumlah 5 orang terdiri dari 1 kepala sekolah, 2 guru, dan 2 orang tua murid. Berdasarkan hasil penelitian dapat disimpulkan bahwa terkait proses pelaksanaan progam parenting terdiri dari: 1. Persiapan membuat perencanan program yang dibuat oleh kepala sekolah dan guru, membentuk kepanitiaan. 2. Pelaksanaan program parenting yang dilaksanakan yaitu seminar, hari konsultasi orang tua, field trip, pertemuan rutin sebulan sekali (parenting), parenting melalui aplikasi grup whatsapp diadakan sebulan sekali; 3. Evaluasi dilakukan melalui percakapan antara kepala sekolah, guru dan orang tua yang membahas mengenai narasumber, materi serta pelaksanaan kegiatan.
\end{abstract}

Kata Kunci: Program Parenting, Proses Pelaksanaan Program Parenting, Hambatan Pelaksanaan Program Parenting

Abstract - The parenting program is a form of activity carried out to harmonize the care and education of children at school and at home. Parenting programs are very important for parents to gain knowledge related to care that is suitable for early childhood growth and development. The purpose of this study is to explain the process of implementing the parenting program starting from the preparation, implementation, and evaluation stages.This study uses a descriptive qualitative approach with data collection techniques in the form observation, interviews, and documentation. Data analysis uses triangulation techniques. The subjects of this study amounted to 5 people consisting of 1 principal, 2 teachers, and 2 parents. Based on the results of the study it can be concluded that related to the implemntation process of the parenting program consists of : 1 . Preparation for planning a program made by the principal and teacher, forming a committee. 2. The implementation of parenting programs such as seminars, parental consultation days, field trip, monthly routine meetings (parenting), parenting through the whatsapp group application is held once a month. 3. Evaluation is carried out through conversations between the principal, teacher and parents who discuss the resource person, the material and the implementation of the activity.

Keywords: Parenting Program, Parenting Program Implementation Process, Obstacles to Parenting Program 


\section{PENDAHULUAN}

$\mathrm{P}$ endidikan anak usia dini merupakan salah satu bentuk penyelenggaraan pendidikan yang menitikberatkan pada arah pertumbuhan dan perkembangan anak. Undang - undang Nomor 20 Tahun 2003 tentang Sistem Pendidikan Nasional menuliskan bahwa "Pendidikan anak usia dini adalah suatu upaya pembinaan yang ditunjukkan kepada anak sejak lahir sampai dengan usia enam tahun yang dilakukan melalui pemberian rangsangan pendidikan untuk membantu pertumbuhan dan perkembangan jasmani dan rohani agar anak memiliki kesiapan dalam memasuki pendidikan lebih lanjut". Pendidikan anak usia dini dapat dilaksanakan melalui 3 jalur yaitu pendidikan formal, pendidikan non formal, dan pendidikan informal. Undang-undang RI Nomor 20 tahun 2003 tentang Sistem Pendidikan Nasional pasal 28, menyatakan bahwa: (1) Pendidikan anak usia dini diselenggarakan sebelum jenjang pendidikan dasar, (2) Pendidikan anak usia dini dapat diselenggarakan melalui jalur formal, nonformal atau informal, (3) Pendidikan anak usia dini jalur formal berbentuk Taman Kanakkanak, Raudhatul Athfal (RA) atau bentuk lain yang sederajat, (4) Pendidikan anak usia dini pada jalur pendidikan nonformal berbentuk kelompok bermain, taman penitipan anak, atau bentuk lain yang sederajat, (5) Pendidikan anak usia dini pada jalur pendidikan informal berbentuk pendidikan keluarga atau pendidikan yang diselenggarakan oleh lingkungan.

Salah satu lembaga pendidikan anak usia dini pada jalur formal adalah Raudhatul Athfal. Raudhatul Athfal merupakan taman kanakkanak yang berada di bawah naungan Kementerian Agama melalui SK Menteri Agama yang dikelola secara profesional oleh guru-guru Raudhatul Athfal dalam wadah IGRA (Ikatan Guru Raudhatul Athfal).

Raudhatul Athfal tidak hanya memberikan layanan pendidikan melainkan juga memberikan layanan program parenting. Secara langsung program parenting memberikan pendidikan untuk orang tua tentang tumbuh kembang anak yang sesuai dengan perkembangannya. Program parenting adalah program pendidikan tentang pengasuhan yang diberikan kepada orang tua agar pengetahuan yang dimiliki orang tua menjadi bertambah tentang tumbuh kembanganak (Gichara, 2013: 19).

Program parenting yang lebih dikenal dengan program pendidikan orang tua yang diberikan di sekolah, juga sejalan dengan program yang dirancang pemerintah. Hal tersebut dapat dilihat di dalam buku petunjuk teknis penyelenggaraan pendidikan anak usia dini berbasis keluarga. Parent dalam parenting memiliki beberapa definisi yaitu ibu, ayah, atau seseorang yang akan membimbing dalam kehidupan baru, seorang penjaga, maupun seorang pelindung. Parent adalah seseorang yang mendampingi dan membimbing semua tahapan pertumbuhan anak, yang merawat, melindungi, serta mengarahkan kehidupan baru anak dalam setiap tahapan perkembangannya (Brooks, 2011: 63).

Menurut Morissson (dalam Winahyu, 2012: 382-383) parenting merupakan suatu kegiatan untuk membantu keluarga supaya dipahaminya perkembangan anak, keterampilan pengasuhan yang sesuai, kondisi rumah yang mendukung pembelajaran anak dan membantu sekolah memperoleh informasi tentang anak. Selanjutnya, menurut Hastuti (2015: 55), secara sederhana pengasuhan dilakukan guna menumbuhkembangkan dan mendidik anak. Pengasuhan dapat diartikan sebagai implementasi dari serangkaian keputusan yang dilakukan orang tua atau orang dewasa kepada anak sehingga anak menjadi bertanggungjawab, menjadi anggota masyarakat yang baik, dan memiliki karakter baik.

Program parenting merupakan upaya memberikan pengetahuan untuk orang tua agar pendidikan yang diperoleh anak di rumah sesuai dengan pendidikan yang diperoleh di sekolah. Mukhtar (2013: 260) mengatakan pendidikan orang tua adalah pendidikan yang diberikan kepada orang tua dalam rangka untuk mengetahui dan mengaplikasikan pendidikan yang tepat dalam mendidik anak usia dini terutama saat anak berada dalam lingkungan keluarga bersama orang tuanya di rumah.

Menurut Kemendiknas (2012: 2) parenting adalah suatu program pendidikan keluarga yang diberikan pada orang tua yang diselenggarakan oleh lembaga PAUD agar orang tua dapat melaksanakan perannya untuk mengoptimalkan tumbuh kembang anak dan dalam rangka menyelaraskan pengetahuan dan keterampilan. 
Materi parenting bisa berupa gizi dan kesehatan, perawatan, pengasuhan, pendidikan dan perlindungan di rumah sehingga anak dapat tumbuh dan berkembang secara optimal, sesuai usia dan tahap perkembangannya. Program parenting atau yang disebut dengan pendidikan keorangtuaan merupakan suatu bentuk kegiatan yang dilaksanakan di lembaga PAUD, program parenting memberikan pengetahuan bagi orang tua terhadap anak terkait dengan mengasuh dan mendidik anak agar anak dapat tumbuh kembang secara optimal yang sesuai dengan tahapan perkembangannya. Bentuk program parenting atau disebut juga dengan bentuk program pendidikan keorangtuaan bagi orang tua yang telah di susun oleh Lembaga PAUD, dalam bentuk Kelas Pertemuan Orang tua; seminar; Field trip; dan Hari konsultasi orang tua. (Latif, 2013: 262)

Pelaksanaan program diselenggarakan melalui 3 tahapan, yakni persiapan atau perencanaan, tahap pelaksanaan, dan tahap evaluasi. Hal tersebut seperti yang tertera pada buku yang dikeluarkan Kemendiknas (2012: 9-21), yaitu:

\section{Persiapan}

Persiapan adalah suatu kegiatan untuk mempersiapkan segala sesuatu yang dibutuhkan dalam pelaksanaan agar terlaksana dengan baik dan tujuan yang disiapkan dapat tercapai. Persiapan yang perlu dilakukan yaitu:

a. Sosialisasi Program Parenting yaitu sekolah melakukan sosialisasi program parenting kepada seluruh orang tua. Sosialisasi dapat dilakukan melalui pertemuan orang tua, melalui buku penghubung, surat menyurat atau edaran, leafleat, booklet, spanduk, brosur dan melalui komunikasi media sosial seperti Facebook, pesan singkat (SMS), WhatsApp, Twitter, dan laman.

b. Pembentukan pengurus program parenting yaitu dapat meliputi pembagian tugas dan penempatan orang-orang dalam pembentukan susunan panitia kegiatan yang terdiri dari ketua, sekretaris, bendahara dan seksi-seksi (komite) yang bertanggung jawab terhadap bidang-bidang teknis yang dibutuhkan dalam mendukung penyelenggaraan program. Contoh: seksi konsumsi, seksi acara, seksi humas.

c. Penyamaan persepsi merupakan kegiatan membuat perencanaan program untuk memperjelas dan kesepahaman orang tua dengan lembaga PAUD yang dilakukan melalui musyawarah dengan Tanya jawab, ceramah, diskusi untuk mencari solusi atas berbagai permasalahan yang dihadapi.

d. Identifikasi kebutuhan yaitu identifikasi kebutuhan informasi (isu-isu penting seputar pendidikan dan tumbuh kembang anak) yang ingin diketahui oleh orang tua tentang pengasuhan yang selama ini dilaksanakan di rumah. Mengidentifikasi kebutuhan untuk orang tua menyangkut aspek materi dalam pendidikan, perawatan, pola asuh, kesehatan dan gizi, perlindungan, stimulasi pendidikan.

e. Penentukan tempat dan waktu, tema, narasumber, sarana dan prasarana, media yang digunakan, metode, target peserta dan daftar hadir.

f. Penyusunan rencana program dan jadwal kegiatan yaitu menyusun rencana program parenting apabila sudah menentukan bentuk kegiatan dan waktu yang akan dilaksanakan.

\section{Pelaksanaan}

Pelaksanaan program merupakan proses menjalankan kegiatan yang telah diprogramkan. Pelaksanaan ini merupakan kesesuaian program dari perencanaan yang sudah dibuat. Daftar kehadiran orang tua, media yang digunakan, target peserta orang tua, tempat dan waktu, narasumber, sarana dan prasarana, dan metode, materi. Pelaksanaan program parenting dapat dilakukan dalam bentuk, antara lain:

a. Kelas Pertemuan Orang Tua

b. Keterlibatan Orang Tua di Kelas Anak

c. Keterlibatan Orang Tua dalam Acara Bersama

d. Hari Konsultasi Orang Tua

e. Kunjungan Rumah

\section{Evaluasi program}

Evaluasi program dilakukan untuk mengetahui efektivitas pelaksanaan program terkait dengan pencapaian tujuan, baik dari keluarga, lembaga PAUD, dan komite sekolah. Evaluasi program ini dilakukan untuk mengetahui keberhasilan dan kekurangan dari program yang telah dilaksanakan, sehingga dalam pelaksanaan berikutnya akan lebih baik lagi dan belajar dari kesalahan yang dilakukan dari sebelumnya. Menurut Kemendiknas (2012: 21) terdapat tiga teknik evaluasi yaitu diskusi, angket, wawancara dan observasi. 
Menurut Kemendiknas (2017: 7) dalam pelaksanaan program tentunya perlu menyiapkan beberapa perlengkapan yang akan digunakan dalam pelaksanaan program, salah satunya adalah materi. Media-media yang digunakan untuk menunjang penyampaian materi antara lain: (1) Lembar info (leaflet, brosur, poster), (2) Flipchart (lembar balik), (3) Audio-visual (VCD, radio, televisi, proyektor, film), (4) Kliping (kumpulan berita dari berbagai media cetak), (5) Booklet, (6) Komik dan buku-buku bacaan pendamping lain, (7) Dan media-media lain yang mendukung.

Salah satu sekolah yang menyelenggarakan program parenting yaitu sekolah Raudhatul Athfal Permata Assholihin, Jakarta. Di sekolah tersebut memberikan layanan program parenting yang disebut dengan "smart parenting". Smart parenting di sekolah tersebut menggunakan alat komunikasi yaitu handphone melalui aplikasi grup whatsapp. Selain itu, smart parenting yang dilakukan sekolah tersebut adalah seminar tentang makanan sehat.

Raudhatul Athfal (RA) merupakan salah satu lembaga pendidikan formal untuk anak usia dini untuk membina anak-anak keluarga Muslim dan memperkenalkan dasar-dasar ajaran agama Islam kepada anak didiknya. Raudhatul Athfal berasal dari bahasa Arab, Raudhah yang berarti taman dan Athfal yang berarti anak-anak. Raudhatul Athfal berarti Taman Kanak-Kanak (Analytica, 2013: 36)

Pelaksanaan program parenting membutuhkan peran dari berbagai pihak terkait, yaitu peran kepala sekolah, guru kelas, dan orang tua dan komite. Menurut Kemendikbud (2017: 11), unsur-unsur yang memiliki peran utama dalam program parenting atau yang disebut juga dengan pendidikan keluarga di satuan PAUD adalah:

1. Peran kepala sekolah: menetapkan kebijakan yang mendukung penyelenggaraan program parenting, menyusun rancangan kegiatan, menjalin hubungan dengan keluarga.

2. Peran guru kelas: Mendukung kebijakan program parenting, menjadi fasilitator antara pihak sekolah dengan orang tua.

3. Peran keluarga: menciptakan lingkungan belajar di rumah yang menyenangkan, memberikan motivasi kepada anak, berpartisipasi aktif dalam kegiatan yang dilakukan di lembaga PAUD.

4. Peran komite sekolah: mendorong, mendukung dan mengkoordinasikan pelaksanaan program.

Berdasarkan uraian tersebut maka dirasa perlu dilakukan penelitian mengenai program parenting dengan judul "Proses Pelaksanaan Program Parenting di Raudhatul Athfal Permata Assholihin".

\section{METODE PENELITIAN}

Penelitian dilakukan di RaudhatulAthfal Permata Assholihin, Jalan Manunggal II RT. 015/02 No. 12B Petukangan Selatan, Kelurahan Pesanggrahan Jakarta Selatan. Pemilihan lokasi penelitian ini didasarkan karena sekolah Raudhatul Athfal Permata Assholihin memiliki layanan program parenting yang diadakan sebulan sekali. Waktu penelitian dari penetapan judul sampai proses pelaporan hasil penelitian dilaksanakan sejak bulan April 2018 hingga September 2018.

Subjek penelitian terdiri 1 kepala sekolah, 2 guru dan 2 orang tua murid di Raudhatul Athfal Permata Assholihin. Pendekatan penelitian yang digunakan adalah pendekatan kualitatif deskriptif yaitu membuat deskripsi atau narasi dari suatu fenomena, tidak untuk mencari hubungan antar variabel, ataupun menguji hipotesis, dan mengumpulkan data yang dikumpulkan berupa kata-kata, gambar, dan bukan angka. Laporan penelitian akan berisi kutipan-kutipan data untuk memberi gambaran penyajian laporan tersebut (Moleong, 2011: 5).

Sumber data yang digunakan didapatkan dari dua sumber data, yaitu data primer dan sekunder. Data primer adalah sumber data yang pertama, yang didapat dari subjek atau objek (Dimyati, 2013: 39). Sumber data primer dalam penelitian ini yaitu kepala sekolah, guru dan orang tua di Raudhatul Athfal Permata Assholihin. Data sekunder adalah sumber data yang diperoleh dari pihak mana saja yang bisa memberikan tambahan data guna melengkapi kekurangandari data yang diperoleh melalui sumber data primer (Dimyati, 2013: 40). Untuk melengkapi penelitian ini, maka peneliti menggunakan sumber data sekunder berupa hasil dokumentasi. 
Teknik pengumpulan data dilakukan dengan cara observasi, wawancara dan dokumentasi. Wawancara adalah bentuk komunikasi antara dua orang, melibatkan seseorang yang ingin memperoleh informasi dari seorang lainnya dengan mengajukan pertanyaan-pertanyaan berdasarkan tujuan tertentu (Mulyana, 2010: 180). Wawancara yang digunakan adalah wawancara terstruktur yang merupakan satu teknik pengumpulan data dengan cara lisan terhadap responden, dengan menggunakan pedoman wawancara yang telah disediakan. Wawancara dilakukan mulai tanggal 19 Juli 2018.

Sementara dokumentasi dilakukan dengan mengambil foto atau video pelaksanaan program parenting di Raudhatul Athfal Permata Assholihin. Menurut Gunawan (2012: 176), dokumen merupakan catatan peristiwa yang berbentuk tulisan, gambar, atau karya monumental dari seseorang. Dokumen merupakan pelengkap dari penggunaan metode observasi dan wawancara dalam penelitian kualitatif.

Teknik analisis data dilakukan dengan cara reduksi data (data reduction), penyajian data (data display), dan kesimpulan atau verifikasi (conclusion drawing) (Miles dan Huberman dalam Sugiyono, 2014: 247). Keabsahan data dilakukan dengan triangulasi sumber.

\section{HASIL DAN PEMBAHASAN}

Raudhatul Athfal Permata Assholihin merupakan sebuah lembaga pendidikan anak usia dini yang berdiri pada Juli 1997. Pendiri Raudhatul Athfal Permata Assholihin yaitu $\mathrm{Hj}$. Sri Utami M.Pd, sebagai kepala sekolah bersama dengan suami. Raudhatul Athfal Permata Assholihin berada di bawah naungan Kementrian Agama. Raudhatul Athfal Permata Assholihin terletak di sebuah area yang cukup luas, hijau, dan asri dengan pepohonan.

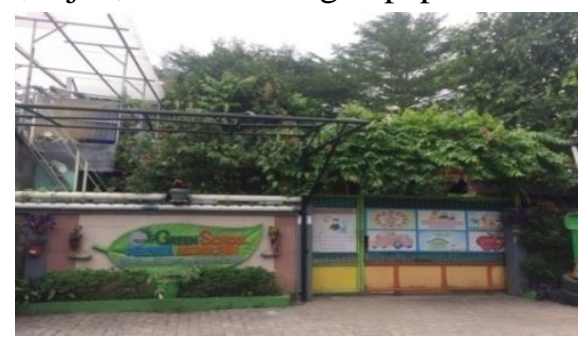

Gambar 1. Lokasi RA Permata Assholihin

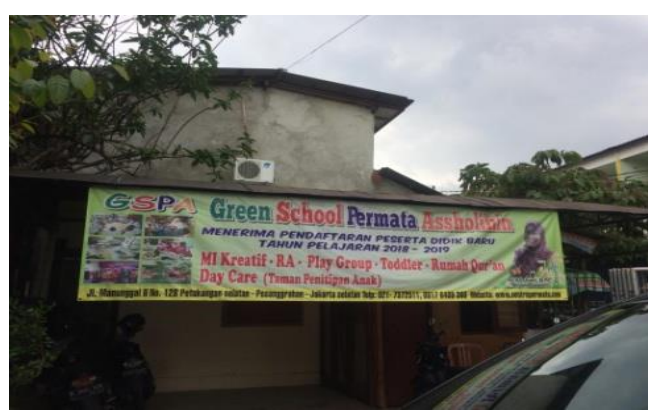

Gambar 2. Tampak Samping Raudhdatul Athfal Permata Assholihin

Tenaga pendidik di Raudhatul Athfal Permata Assholihin terdiri dari sembilan guru. Tenaga pendidik sebagian besar berkualifikasi sarjana (S1).

\section{Proses Pelaksanaan Program Parenting \\ a. Persiapan}

Pelaksanaan program parenting, diawali dengan penyusunan rencana program parenting yang dilakukan oleh kepala sekolah. Persiapan program parenting dimulai dari membuat jadwal, tanggal, waktu, dan bentuk program parenting yang akan dilaksanakan, kemudian merencanakan tema, materi yang berbeda setiap bulannya, serta menentukan narasumber yang sesuai dengan tema. Pelaksanaan program parenting biasanya dilakukan di ruang sentra bahan alam dan sentra main peran, di halaman, ataupun ruangan SD. Sarana pendukung kegiatan yang digunakan adalah laptop, bahan materi yang akan disampaikan, konsumsi, infokus, mike, serta layar. Adapun metode yang digunakan dalam program parenting adalah tanya jawab, praktek langsung, dan berdiskusi. Pihak sekolah juga membuat target peserta yang hadir dalam kegiatan program parenting.

Selanjutnya sekolah mensosialisasikan kegiatan melalui komunikasi dengan orang tua, memberikan surat edaran, serta memberikan informasi melalui handphone berupa grup whatsapp. Adapun pembentukan susunan panitia pelaksana program parenting bulanan hanya dari pihak sekolah. Untuk parenting tahunan susunan ketua pelaksana dan sekretaris berasal dari sekolah yaitu kepala sekolah dan guru sekolah. Untuk bendahara ditentukan 2 orang yaitu dari pihak sekolah dan dari pihak komite sekolah. Anggota komite dan orang tua murid lain bisa menjadi seksi atau anggota panitia dalam menunjang terlaksananya program parenting. 
Seperti yang dikatakan oleh Lickona (2012: 84) bahwa sekolah memberikan pemberitahuan mengenai pelaksanaan program parenting secara berulang melalui beberapa media, misalnya dengan cara memasang pengumuman acara pada situs web sekolah, undangan kartu pos, mengirim e-mail pengingat, dan menghubungi orang tua melaui pesan secara otomatis.

Persiapan yang telah dilakukan pihak sekolah sudah cukup baik, namun dapat dikatakan belum maksimal. Pihak sekolah belum melakukan penyamaan persepsi antara orang tua dengan lembaga dalam membuat perencanaan program untuk memperjelas dan menemukan kesepahaman antara orang tua dengan lembaga PAUD yang dilakukan melalui musyawarah dengan tanya jawab, ceramah, diskusi untuk mencari solusi atas berbagai permasalahan yang dihadapi. Hal tersebut sebagaimana yang disampaikan dalam buku yang dikeluarkan Kemendiknas (2012: 9).

\section{b. Pelaksanaan}

Program parenting ini dilaksanakan pada Sabtu, 7 April 2018 tepatnya di dalam ruangan sentra bahan alam dan sentra main peran. Bentuk program parenting pada hari itu adalah seminar dan konsultasi orang tua. Bentuk program yang dilakukan tersebut sesuai dengan yang diungkapkan Latif (2013: 262), yaitu bentuk program parenting mencakup seminar, konsultasi orang tua, dan flied trip.

Pelaksanaan parenting di sekolah dilakukan dari jam 08.00-12:00 WIB. Sebelum mulai, orang tua wajib mengisi daftar hadir yang sudah disediakan, kemudian mengambil hasil tes kematangan anak lalu masuk ke dalam ruangan. Selain bentuk tatap muka, parenting juga dilakukan melalui grup whatsapp, sekolah dengan memberikan materi parenting. Bentuk kegiatan tersebut dilakukan sebulan sekali.

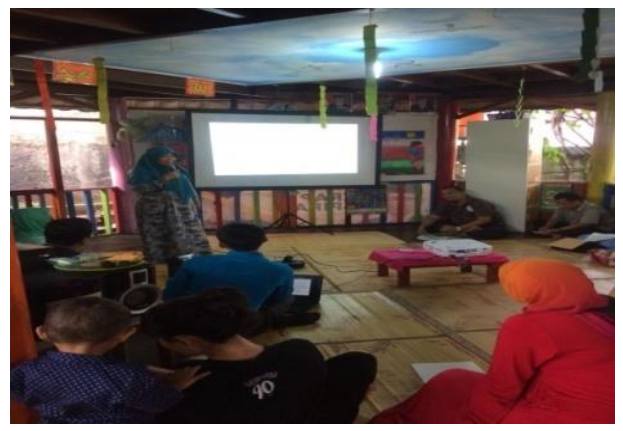

Gambar 3.Seminar Parenting
Proses pelaksanaan kegiatan diawali dengan berdoa, sambutan, perkenalan diri, yang kemudian dilanjutkan dengan pemaparan materi oleh narasumber. Salah satu materi yang disampaikan adalah materi dengan tema "Mendidik Anak Jaman Now". Metode yang digunakan pada hari itu berupa tanya jawab. Hal tersebut telah sesuai dengan apa yang diungkapkan oleh Sudjana (2009: 32), bahwa metode tanya jawab merupakan salah satu metode mengajar (menyampaikan materi) yang paling efektif dan efisien dalam proses pembelajaran. Setelah seminar selesai, kegiatan dilanjutkan dengan konsultasi. Pada kegiatan tersebut, orang tua dapat berkonsultasi kepada ahli dalam bidangnya yaitu psikologi anak. Orang tua dapat berkonsultasi tentang permasalahan perkembangan anak baik di rumah maupun di sekolah dengan cara bergiliran.

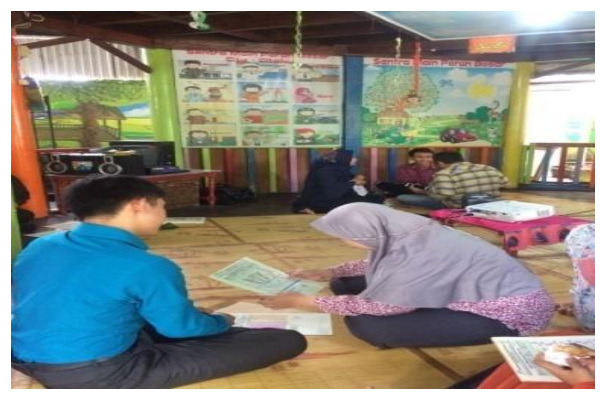

Gambar 4.Hari Konsultasi Orang Tua

\section{c. Evaluasi}

Setelah kegiatan dilaksanakan, kepala sekolah berserta guru dan orang tua murid melakukan evaluasi. Evaluasi dilakukan sekolah dalam bentuk percakapan antara kepala sekolah, guru dan orang tua murid. Percakapan itu sendiri dapat dilakukan melalui Handphone maupun tatap muka. Bentuk evaluasi yang dilakukan di sekolah sesuai yang diungkapkan Trianto (2011: 103) yang mengatakan bahwa percakapan merupakan salah satu metode evaluasi bentuk non tes.

\section{Hambatan dalam penyelenggaraan program parenting}

Menciptakan kerjasama yang kuat antara sekolah dan orang tua bukan merupakan hal yang mudah. Tentunya terdapat beberapa hal yang menghambat terciptanya hubungan kerjasama antara guru dengan orang tua dalam pelaksanaan program parenting. Dari hasil observasi penelitian terdapat hambatan dalam proses pelaksanaan program parenting. 
Hambatan muncul dari segi waktu. Ketika acara dimulai pukul 08:00 masih ada beberapa orang tua yang datang terlambat dan tidak hadir, padahal sebelumnya dari pihak sekolah sudah menginformasikan melalui surat edaran dan memberitahukan kepada orang tua lebih dari sekali melalui Handphone yaitu grup whatsApp.

\section{SIMPULAN DAN SARAN}

Berdasarkan pembahasan pada sub fokus penelitian, maka dapat disimpulkan bahwa proses pelaksanaan program parenting di Raudhatul Athfal Permata Assholihin yaitu: pertama, Persiapan program yang diawali dengan membuat perencanaan program yang dibuat oleh kepala sekolah dan guru. Perencanaan meliputi tempat, tanggal, waktu, tempat, narasumber, tema, media, sarana dan prasarana maupun bentuk program parenting, selanjutnya membentuk susunan panitia (ketua, bendahara, sekretaris dan seksi-seksi), parenting bulanan hanya dari pihak sekolah, parenting setahun melibatkan komite atau orang tua menjadi bendahara, sekretaris dan seksi-seksi panita dalam menunjang terlaksananya program parenting; kedua, Pelaksanaan program, diawali dengan beberapa persiapan yang meliputi ruangan, konsumsi, media, daftar kehadiran.

Kegiatan dilaksanakan pada hari Sabtu, dimulai pukul 08:00 - 12:00 WIB dan program parenting yang dilaksanakan yaitu seminar, hari konsultasi orang tua, field trip, pertemuan rutin sebulan sekali (parenting), parenting di aplikasi grup whatsapp diadakan sebulan sekali. Dan ketiga, Evaluasi program di Raudhatul Athfal Permata Assholihin adalah diskusi antara kepala sekolah dengan guru, kemudian evaluasi dengan orang tua murid dilakukan melalui percakapan antara kepala sekolah, guru dan orang tua yang membahas mengenai narasumber, materi dari pelaksanaan. Percakapan dilakukan melalui handphone maupun tatap muka.

Hambatan yang ditemukan dalam pelaksanaan program parenting yaitu dalam segi waktu. Masih ada orang tua yang telat hadir maupun berhalangan hadir, meskipun telah diinformasikan pihak sekolah sebelum pelaksanaan baik melalui surat edaran maupun melalui handphone yaitu Grup whatsApp.
Berdasarkan hasil penelitian, maka dapat disarankan kepada kepala sekolah agar mengajak orang tua untuk bermusyawarah dalam membuat penyusunan perencanaan program parenting agar orang tua dapat mengetahui program yang akan dilaksanakan. Selain itu orang tua dapat memberi saran atau kritikan. Kepala sekolah hendaknya juga mengajak orang tua ikut serta menjadi narasumber agar dapat terjalin kerjasama antara pihak sekolah dan orang tua. Selanjutnya dalam proses evaluasi kepala sekolah tidak hanya melakukan evaluasi percakapan antara kepala sekolah, guru dan orang tua, tetapi evaluasi bisa dengan cara lain yaitu berdiskusi antara pihak sekolah dengan orang tua.

Saran untuk orang tua yaitu diharapkan kepada orang tua tidak datang terlambat dan datang sesuai dengan jadwal yang sudah ditetapkan agar pelaksanaan kegiatan parenting berjalan dengan lancar dan tepat waktu. Orang tua sesekali dapat menjadi narasumber untuk kegiatan program parenting agar orang tua dapat berpartisipasi.

\section{DAFTAR PUSTAKA}

Brooks, J. (2011). The process of parenting. Edisi ke delapan. Yogyakarta: Pustaka Pelajar.

Direktorat Pembinaan Pendidikan Keluarga. (2012). Model pelaksanaan program pendidikan keorangtuaan di lembaga pendidikan anak usia dini. Jakarta: Kementerian Pendidikan dan Kebudayaan.

Direktorat Pendidikan Anak Usia Dini. (2012). Pedoman penyelenggaraan pendidikan anakusia dini berbasis keluarga. Jakarta: Departemen Pendidikan Nasional.

Gunawan, I. (2012). Metode penelitian kualitatif: teori dan praktik. Jakarta: Bumi Aksara.

George S.M. (2012). Dasar-dasar pendidikan anak usia dini. Edisi Kelima. Jakarta: PT Indeks.

Islamica, A. (2013). Raudhatul Athfal: urgensi dan pengaruhnya dalam pertumbuhanan anak usia dini (urgensi dalam pertumbuhan anak usia dini). Kandidat doktor Pendidikan Islam. Vol. 2 No. 1. 
Kementerian Pendidikan dan Kebudayaan. (2017). Petunjuk teknis pelibatan keluarga pada penyelenggaraan anak usia dini. Jakarta.

Kementerian Pendidikan dan Kebudayaan. (2017). Sahabat keluarga. Jakarta.

Moleong, L.J. (2011). Metodologi penelitian kualitatif. Bandung: PT Remaja.

Latif, M., dkk. (2014). Orientasi baru pendidikan anak usia dini teori dan aplikasi. Jakarta: Kencana Prenada Media Group.
Sugiyono. (2014). Memahami penelitian kualitatif. Bandung: Penerbit Alfabeta.

Sugiyono. (2009). Metode penelitian kuantitatif, kualitatif dan $R \& D$. Penerbit Alfabeta.

Undang-undang RI Nomor 20 tahun 2003 tentang sistem pendidikan nasional. 